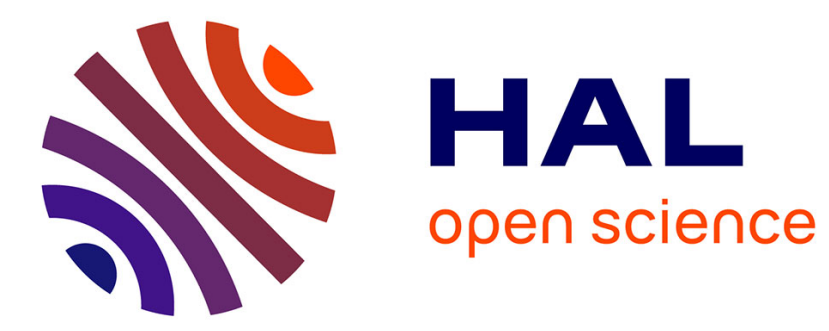

\title{
Entrepreneurial Orientation: do we actually know as much as we think we do?
}

\author{
Kathleen Randerson
}

\section{To cite this version:}

Kathleen Randerson. Entrepreneurial Orientation: do we actually know as much as we think we do?. Entrepreneurship and Regional Development, 2016, 28 (7-8), pp.580 - 600. 10.1080/08985626.2016.1221230 . hal-01392200

\section{HAL Id: hal-01392200 \\ https://hal-audencia.archives-ouvertes.fr/hal-01392200}

Submitted on 9 Nov 2016

HAL is a multi-disciplinary open access archive for the deposit and dissemination of scientific research documents, whether they are published or not. The documents may come from teaching and research institutions in France or abroad, or from public or private research centers.
L'archive ouverte pluridisciplinaire HAL, est destinée au dépôt et à la diffusion de documents scientifiques de niveau recherche, publiés ou non, émanant des établissements d'enseignement et de recherche français ou étrangers, des laboratoires publics ou privés. 
Kathleen Randerson - Audencia Business School

R'nB Lab - Research Center of Audencia Centrale Nantes

http://dx.doi.org/10.1080/08985626.2016.1221230

\section{Entrepreneurial Orientation: Do we actually know as much as we think we do?}

\section{Abstract}

The focus of this paper is on firm-level entrepreneurial behaviours and the processes that lead to them, known as Entrepreneurial Orientation. Despite the popularity of this construct, we argue that extant EO research suffers from major limitations linked to definitional inconsistencies and measurement issues. We present five distinct conceptualisations of EO in order to frame further research in the positivist mode. Moreover, we show that to gain a holistic and robust understanding of firm level entrepreneurship, works from other research traditions and philosophies of science are needed. In this respect, the European research tradition and its wide variety of fields of research and research methods can offer a contextualised view of firm-level entrepreneurial behaviours and processes. Works embedded in the social constructionist philosophy of science might also offer an understanding of how, when, and why actors of different levels act do so and the likely outcomes of these actions as well as the interplay and divergence among these actors and levels. Works embedded in the pragmatic approach, illustrated by effectuation, could also contribute to a holistic understanding of the phenomenon. Finally, we call for researchers to be attentive to the need to align their conceptualisations, research methods, and philosophies of science.

Keywords: corporate entrepreneurship, firm-level entrepreneurial behaviour, entrepreneurial orientation, critique, European research tradition, constructionism, pragmatism 


\section{Introduction}

Covin and Lumpkin (2011) state that Entrepreneurial Orientation (EO) is seen as an 'annoying construct', and that 'for every scholar who employs the construct of EO in his or her research, there is another scholar who simply wishes it would exit the scholarly conversation' (Covin and Lumpkin 2011, 859). Our intention is not to see EO exit the scholarly conversation, but rather to demonstrate that it reflects an idea of entrepreneurship that has been institutionalized in a manner that makes it hollow: extant research on firm-level entrepreneurship behaviours has calcified around the EO construct, whereas societies may in fact demonstrate different entrepreneurial behaviours and embrace different meanings of entrepreneurship (Fayolle et al. 2013).

Although EO has been defined in many manners and that many of these definitions are incompatible (George and Marino 2011, 992), the construct is currently used to measure firmlevel entrepreneurial behaviours through three to five dimensions (innovation, proactiveness, risk-taking, autonomy and competitive aggressiveness) (Covin and Lumpkin 2011). EO research has contributed to developing the field of entrepreneurship because it was among the pioneers to research entrepreneurial behaviours of organisations rather than individuals (Zahra, Randerson, and Fayolle 2013). We will develop each of these points in the present work.

EO has attracted a great deal of scholarly attention over the past 30 years. Covin and Lumpkin even argue that it has come to eclipse Corporate Entrepreneurship (CE) (Covin and Lumpkin 2011, 855). Covin and Lumpkin note that many scholars consider EO to be an aspect of CE; for others (George and Marino 2011), EO is purely and simply synonymous with CE. In their essay, Zahra, Randerson, and Fayolle (2013) position EO as a component of CE research, arguing 
that the former reflects 'a firm's disposition to become entrepreneurial in its operations' and the second refers to "the gamut of informal and formal activities the firm actually undertakes in identifying, evaluating and exploiting opportunities through internal (e.g. the creation of new venture units) and external (e.g. alliances) means' (364). They attribute the EO/CE confusion seen in the work of some authors to the fact that both these branches of the literature are based on the article by Miller (1983). In their essay these authors do not delve into the study of EO or its (dis)connectedness with CE. We adopt the distinction between EO and CE of Zahra, Randerson, and Fayolle (2013) as well as Miller's (1983) conceptualisation of EO as being revealed through firm-level entrepreneurial behaviour. In the present article, the term 'organisational entrepreneurship' refers to Gartner's (1985) view of entrepreneurial processes as the emergence of new organisations.

Limiting the study of entrepreneurship in organisational settings to EO, be it by confusion (George and Marino 2011) or opportunism (Covin and Lumpkin 2011; Miller 2011), precludes creating knowledge about how organisations develop or maintain this disposition to become entrepreneurial. In addition, the manner in which the construct is used in most extant research excludes mining the richness of the entrepreneurial process and its idiosyncrasies (Gartner 1985), whereas the link between entrepreneurial behaviour and individual and organisational processes is actually the heart of the initial debate (Miller 1983, 2011; Gartner 1985). Miller's (1983) article was ground breaking precisely because it opened up entrepreneurship to firms and was novel because it shifted the focus away from the traditional view (i.e. the identification of entrepreneurship with a dominant organisational personality and the innovative abilities of this entrepreneurial actor) in order to decipher the entrepreneurial activity of the firm (Miller 1983, 770). 
To unveil the processes of entrepreneurship and the organisational factors that foster and impede it in different organisational configurations, Miller (1983) creates a dependent 'entrepreneurship' variable defined as the aggregate average of three dimensions, namely risktaking, innovation, and proactiveness, which best reflect the ideas of some entrepreneurship classics of the day (Miller 2011, 874), until then essentially applied to the individual entrepreneur. In classic theory, an entrepreneur takes risks in order to make great gains, is an agent of innovation, and is quick to act when he or she discovers or identifies an opportunity.

Like most mainstream entrepreneurship research, EO is embedded in a positivist philosophy of science (Covin and Lumpkin 2011; Covin and Wales 2012), in which entrepreneurial phenomena are seen as empirical objects with well-defined descriptive properties and are studied from the perspective of an outsider using methods that emphasise hypothesis testing, inferential statistics, and internal validity (Burg and Romme 2014). On the contrary, seeing organisational entrepreneurship as a form of socially constructed reality offers a way of connecting various entrepreneurship topics (Gartner, Bird, and Starr 1992). The social constructionist perspective considers entrepreneurship to be the fruit of how entrepreneurs and their stakeholders make sense of the world (Burg and Romme 2014; Steyaert and Katz 2004) and mobilises research methods that are imaginative, critical, and reflexive precisely in order to cultivate a critical sensibility to hidden assumptions (Gartner 2007a, 2007b) based on qualitative data such as case studies or grounded theory. This perspective offers other possible entrepreneurial behaviours such as acting 'as if' (Gartner, Bird, and Starr 1992), which begins a cycle of interactions with elements of the surrounding environment.

Academic fields make progress when there is consensus on the key building blocks and constructs (George and Marino 2011), which is the platform for the accumulation of knowledge. 
However, extant EO research aggregates behaviours at the firm level without capturing the processes that lead to this outcome, whereas firm-level entrepreneurial behaviour is actually the result of (intra)organisational processes (Gartner 1985). Moreover, although there is consensus that researching firm-level entrepreneurial behaviour is important, a number of questions remain unaddressed because of the institutionalization of the dominant paradigm. Outstanding research such as 'what behaviours other than innovation, proactiveness, and risk-taking can be considered to be entrepreneurial?' and 'how can other research modes or philosophies of science shed light on firm-level entrepreneurship?' remain unaddressed due to the institutionalization of the dominant paradigm.

To addresses these issues, we offer a constructive critique of extant EO research and suggest paths for clarifying and expanding research on firm-level entrepreneurship. We begin by highlighting the strengths of EO, related to its popularity and novelty. In the second section, we review the barriers that hinder the construct, which derive from definitional contradictions,

measurement issues, and differing conceptualisations. We then identify five conceptualisations of EO that have remained unrecognised. In the fourth section, we identify potential next steps for future research, both on the extant conceptualisations and in terms of bringing other research traditions or philosophies of science to the debate.

\section{The strengths of EO}

\section{The popularity of $\mathrm{EO}$ is a strength for the construct, the field of entrepreneurship, and beyond}

The prevalence of EO has had positive implications for research on firm level entrepreneurship. Previous studies have established the pertinence of EO constructs composed of three to five common dimensions (innovation, proactiveness, risk-taking, autonomy, competitive 
aggressiveness). An EO construct can be reflective or formative. It can be used to study the organisational and environmental factors leading to it and its financial and non-financial consequences.

The popularity of EO can be seen through the sheer number of publications devoted to the subject. A Google Scholar search (March 27, 2016) shows 356,000 hits, while searching EBSCO Business Source Complete for research with 'entrepreneurial orientation' in the title or keywords yields 510 results. Lumpkin and Dess’s 1996 paper (Lumpkin and Dess 1996) won the 2009 IDEA Awards Foundational Paper award from the Entrepreneurship Division of the Academy of Management.

The construct has also brought benefits to the field of entrepreneurship. Indeed, despite the present critique, EO research has offered timely, interesting, and important contributions to the understanding of firm-level entrepreneurship, such as the theoretical explorations of its antecedents and consequences (Lumpkin and Dess 1996; Zahra 1991, 1993), its relationship with internationalisation (Covin and Miller 2014; Slevin and Terjesen 2011), and its influence on organisations (Wales, Monsen, and McKelvie 2011). The popularity EO research also has broader positive implications, being used in neighbouring fields including human resource management (e.g. Hayton, Hornsby, and Bloodgood 2013), family business (e.g. Sciascia and Bettinelli 2013; Zellweger and Sieger 2012; Zellweger, Nason, and Nordqvist 2012), and supply chain management (e.g. Li, Liu, and Liu 2011).

This popularity in and beyond entrepreneurship research is more related to the ease of use of the construct than to its social utility. The scales often used to measure it are perceived as validated, making EO research 'too easy', with the construct considered to be already legitimised 
(Miller 2011). However, as we show in this paper, the scales are not as robust as we might hope, particularly in considering their widespread use. Careerist considerations from the pressure to produce research and the relative ease with which this can be achieved using the EO construct(s) have come to overshadow the social utility of the original conceptualisation, which is related to the shift in the focus of entrepreneurship research from individual to firm-level behaviours and the processes that lead to them.

\section{A firm level construct, based on individual actions}

These different conceptualisations share a common point: this firm-level behaviour is the consequence of individual or team actions. For Miller $(1983,770)$, the entrepreneurial role can be performed not only by a traditional entrepreneur, but also by 'planning' or 'ventures' offices, or even at lower levels of the hierarchy in $R \& D$, engineering, marketing, or production departments. Miller's work aimed to identify the underlying mechanisms or structures that shape firm-level entrepreneurship, moving beyond the focus on the firm or individual to unveil the processes that cut across departments and individuals. Identifying firm-level entrepreneurship as a multi-level phenomenon is important, because individuals act according to their motivations and environment (Gartner 1985), and because dynamic actions/reactions determine the processes and outcomes at different levels of organisational hierarchy: top-managers, managers or nonmanagerial employees.

Miller was not alone in his quest to look beyond the figure of the entrepreneur to disclose the processes involved (e.g. Gartner 1985; Kanter et al. 1990; Burgelman 1983, 1996). However, other approaches have received much less scholarly attention than the 'extension' of Miller's work by Covin and Slevin (1989, 1991) (Zahra, Randerson and Fayolle 2013). Notwithstanding 
the widespread use of the concept in entrepreneurship and other fields, previous research thus presents important lacunae.

\section{The limitations of EO}

We now identify issues related to definitional inconsistencies, measurement tools and research design, which allow us to assert that there are at least five different conceptualisations of EO.

\section{Definitional inconsistencies}

These inconsistencies are the fruit of the misunderstanding of Miller's initial work. The popularity of EO curtailed scholarly debate about what firm-level entrepreneurship can be instead of inducing it.

\section{EO: The fruit of the misunderstanding}

The focus of Miller's (1983) work was not the definition of firm-level entrepreneurship, but the identification of the underlying mechanisms, in different types of organisations, that lead to entrepreneurship being defined ad hoc (innovation, risk-taking, and proactiveness). In his commentary on this seminal article Miller $(2011,874)$ stresses:

\footnotetext{
'Indeed, table III of the 1983 article demonstrated that the firm types differed significantly in the extent to which they exhibited each of the three component variables, and Appendix I showed that these components had rather different sources even within a given type — so, for example, in the simple firm, proactiveness and risk were associated with scanning activity, whereas innovation was not. Such discrepancies were the rule, not the exception, and now I am sorry I did not stress that point more.'
}

The aggregate dependent variable (which has become EO) has been taken out of its initial context (designed as a dependent variable to identify the organisational properties that lead to this result) 
to become an independent variable explaining firm performance (Covin and Slevin 1991), and employed in multiple attempts to model firm-level entrepreneurial behaviour (e.g. Covin and Slevin 1991; Ireland, Covin, and Kuratko 2009; Jennings and Lumpkin 1989; Kuratko et al. 1993; Lumpkin and Dess 1996; Zahra 1991, 1993).

EO is most often measured by using a variation of the initial scales (George and Marino 2011; Rauch et al. 2009); however, these scales are misused. Covin and Wales (2012, 691) admit that 'the Miller/Covin and Slevin (1989) scale was intended to operationalise the construct of EO as originally discussed by Miller (1983), the scale as it's commonly employed does not do this.' We push this analysis even further: when Covin and Slevin $(1989,1991)$ move innovativeness, proactiveness, and risk-taking from dependent variables to independent variables, they ignore Miller's $(1983,780)$ fundamental assumptions. They use an adapted version of Miller's scales to measure entrepreneurship as a means of achieving firm performance, whereas the construct and the scales were conceived to identify the processes that lead to this result. In so doing, they create a new conceptualisation of the construct. This is also the case for Lumpkin and Dess's (1996) 'clarification' in which they maintain the status of the independent variable and add two dimensions (autonomy and competitive aggressiveness). The haste of both sets of authors (Covin and Slevin, Lumpkin and Dess) blinded them to the pitfalls of importing, extending, and modifying the aggregate entrepreneurship variable (Zahra and Newey 2009, 1068).

It is important to emphasise that the term 'Entrepreneurial Orientation' has been subject to a wide range of definitions, many of which are mutually incompatible (George and Marino 2011, 992). Although EO was coined by Lumpkin and Dess in 1996, the term has been used to refer to different conceptualisations (e.g. Miller 1983; Covin and Slevin 1989, 1991; Lumpkin and Dess 1996; Kreiser, Marino, and Weaver 2002; Anderson et al. 2015). George and Marino (2011, 994) 
use the work of Chimezie and Osigweh (1989) and Satori (1970) to demonstrate that the EO concept suffers from a lack of precision because its extension or breadth of application has increased (i.e. it has been applied to other domains), while its intension, or collection of encompassed properties, has decreased (e.g. by defining EO research as mobilising fewer than three dimensions; see Avlonitis and Salavou 2007; Knight 1997; Merz and Sauber 1995). It has also been stretched: this involves increasing a concept's extension without a concurrent decrease in its intension, resulting in a concept that is extremely broad and difficult to distinguish from other concepts in any meaningful way. However, we show that EO is not one broad concept, and that there are in fact multiple conceptualisations. As a consequence, it has become extremely difficult to contribute to a specific body of knowledge because scholars use the empirical results from one conceptualisation in studies investigating another. We need to be attentive to the conceptualisation we embrace, and respect its fundamental assumptions and measurement method (Covin and Wales 2012; Wales 2016).

\section{Alternative definitions of firm-level entrepreneurship are unexplored}

The definition of entrepreneurship based on innovation, proactiveness, and risk-taking is derived from a behavioural perspective. Other perspectives would imply the use of other, adapted variables. For example, to investigate the psychological perspective, we could find the variable need for achievement. Adopting a process approach would mean focusing on organisational emergence. In addition, the definition of EO as innovation, proactiveness, and risk-taking carries the assumption that firms deploy the same entrepreneurial behaviours as individuals. Spontaneously, scholars could question the behavioural approach. For example, which behaviours can be considered entrepreneurial (Gartner, Bird and Starr 1992)? Can other behaviours be considered (i.e. are entrepreneurial behaviours culturally bound)? Do entrepreneurs 
recognise themselves as such through their behaviour (Fletcher 2006; Popp and Holt 2013; Williams and Nadin 2013)? EO, like the majority of mainstream entrepreneurship research, is underpinned by the assumption that entrepreneurship is linked to the entrepreneur and it is universally desirable and beneficial (Miller 2011, 877). In addition, considering that most conceptualisations of EO adopt firm performance as the primary outcome, performance through entrepreneurship is considered desirable; in this deterministic stance, ethics are utilitarian and assumed. These assumptions curtail asking interesting and important research questions such as how the perceived desirability of entrepreneurship varies in different cultures (Dodd, Jack, and Anderson 2013) and what are the manifestations of the "dark side" of entrepreneurship as well as its consequences (Birkinshaw 2003, Karmann et al. 2016). It also restricts attempts to unveil the underlying processes (Hjorth, Jones, and Gartner 2008).

National cultures embrace different perceptions of entrepreneurship and its desirability (Fayolle, Basso, and Bouchard 2010; Hayton, George, and Zahra 2002; Slevin and Terjesen 2011): entrepreneurship may be valued (e.g. United States, Ireland) or less so (Hungary, Japan). Even more importantly, the behaviours considered to be entrepreneurial may vary according to the national culture. The standard dimensions of risk-taking, innovation, and proactiveness may be less relevant than behaviours such as energy, initiative, and adaptation (Slevin and Terjesen 2011), 'bricolage' (i.e. creating something from nothing; Baker and Nelson 2005), or effectuation (Sarasvathy 2001).

Understanding those behaviours considered to be entrepreneurial in a specific cultural context matters. Previous researchers have not taken the time to question whether the standard dimensions are the most appropriate for characterising organisational-level entrepreneurial behaviour, either in each specific culture or globally. In other words, we are comparing 
companies around the world to a yardstick formulated in the United States (Terjesen and Slevin 2011) and developed in a positivist stance (Covin and Lumpkin 2011; Covin and Wales 2012). This is problematic because the list of top 100 firms reshaping global industries according to the Boston Consulting Group (2011) includes firms from Argentina, Brazil, Chile, China, Egypt, Hungary, India, Indonesia, Malaysia, Mexico, Russia, and Saudi Arabia. Considering that entrepreneurial firms reshape industries and the dearth of research on culturally specific entrepreneurial behaviours, we have no means of knowing which behaviours lead to the success of these firms. Moreover, the paucity of research from other traditions or modes (Down 2013; Burg and Romme 2014) hinders a fine-grained contextualised understanding.

\section{Measurement issues}

The measurement of the phenomenon has largely overshadowed the study of EO itself. Pending issues to be addressed include the terms of the scales habitually used to measure EO and the research design that has come to be the norm.

\section{The dominant measurement approach to EO precludes it from achieving its intended goal}

Miller's original work focused on identifying the key mechanisms inducing a firm to demonstrate innovative, proactive, and risk-taking behaviours, all of which are contextually embedded. Miller $(2011,880)$ notes that 'it is not just type of entry but context, richly characterised, that may influence the entrepreneurial process'. The measurement tools used in extant EO research preclude gaining an understanding of the variety and potential idiosyncrasies of the processes involved. Indeed, considering that processes are a succession of actions accomplished by individuals or teams, and that these processes influence and are influenced by environmental, individual, and organisational factors (Gartner 1985), entrepreneurial processes are diverse and 
distinctive.

Although EO has been defined as the 'processes, practices, and decision-making activities that lead to new entry' (Lumpkin and Dess 1996, 136), the way in which it is currently used prevents us from gaining an understanding of these processes. In fact, there is a divergence between the starting notion of the process and its subsequent operationalisation. The process (EO) is treated as a fixed entity (independent variable) where the dimensions are used to represent the process and link the independent variable (EO) to the outcome of interest, here firm performance (McMullen and Dimov 2013). Setting EO as an independent variable places the processes in the proverbial black box, obscuring important nuances in the processes, structures, and underlying mechanisms as well as in the 'time' element. This is problematic since the initial goal of firm-level entrepreneurial behaviour research was precisely to unveil these idiosyncrasies; moreover, consensus formed around the initial dimensions, which were assumed to represent firm-level entrepreneurial behaviour, despite the scarcity of scholarly debate on this issue. Indeed, the debate has focused on the measurement of EO than on the actual principle itself or its components, as we discuss below.

\section{The Miller/Covin and Slevin scale}

Until recently, EO research has focused on dimensionality and measurement, or EO's relationship with performance. However, significant issues cloud the so-called the Miller/Covin and Slevin scales. Several scholars (Hansen et al. 2011; Knight 1997; Kreiser et al. 2010; Kreiser, Marino, and Weaver 2002) worked to establish the validity and dimensionality of the scale. Yet, their use of different versions or approaches prevented them from validating one scale and one conceptualisation, instead inadvertently creating new conceptualisations. 
Of these works, Knight (1997) establishes the overall validity of an eight-item scale in terms of the consistency, pattern of facture structure, internal consistency, and convergent and discriminant validity of Covin and Slevin's co-varying conceptualisation of EO, finding that double-loadings pose a problem for only one item of the proactiveness dimension. Kreiser, Marino, and Weaver (2002) study a different eight-item version of this scale and conclude that the scale achieves a better fit when modelled with three sub-dimensions that display significant independent variance. To establish cross-cultural validity, the authors choose countries that are culturally close to each other as well as to US culture. The 'cross-cultural validity' of their measure therefore suffers from serious bias. They rectify this caveat in their 2010 study (Kreiser et al. 2010), where the between-country analysis provides evidence of the important differences in levels of risk-taking and proactiveness between countries and links these differences to the unique attributes of the institutional environment: national culture does indeed matter.

Lumpkin, Cogliser, and Schneider (2009) investigate the Lumpkin and Dess conceptualisation further. In their comparative study, they use the nine-item Covin and Slevin scale and a scale under development and include additional items for innovation (2), proactiveness (1) and risk (1) as well as a set used to measure autonomy (an additional dimension). Their findings indicate, 'either problems in the conceptual definitions of the EO construct or problems with scale items used quite often in measuring EO, or both.' (Lumpkin, Cogliser, and Schneider 2009, 4).

The common trend in these works is the reduction in the number of items used to measure the construct, the use of different versions of the scale, and the use of the same scale to measure different conceptualisations. Along with Anderson et al. (2015), we point out the general underexploitation of negative results or limitations, which could have helped advance research on the 
topic. For example, Kreiser, Marino, and Weaver (2002) explicitly indicate that the three subdimensions should be used to observe differential relationships between themselves and other variables. In their meta-analysis of the relationship between EO and performance (i.e. independently varying), Rauch and colleagues (2009) note that of the 51 studies included, 37 use a summated concept of EO (co-varying). Finally, in their examination of empirical studies of EO, George and Marino $(2011,1003)$ show that 54 of the 61 studies examined use a summated scale (co-varying) of one form or another.

The issues commonly identified with these scales include that (i) the items only question top managers, leading to results with a 'sole respondent' bias; (ii) it is unclear whether several of the items assess individual or group behaviours; and (iii) the question of whether certain items assess behaviours or attitudes remains. Beyond these shortcomings, we note that Anderson et al.'s (2015) conceptualisation is the only approach to address the issue of attitudes versus behaviours, leading these authors to create the lower order dimensions of attitude and behaviour, and incidentally an additional conceptualisation. Through the above developments, we see that works aiming to validate measurement tools contribute to the creation of the five conceptualisations of EO now presented in detail.

\section{Five conceptualisations of EO}

According to George and Marino $(2011,899)$ there is only one EO construct, whereas Covin and Lumpkin $(2011,859)$ and Wales (2016) suggest two principal conceptualisations: the first is based on the works of Miller (1983) and Covin and Slevin (1989), while the second is based on the findings of Lumpkin and Dess (1996). Wales (2016) suggests taking the 'Miller/Covin and Slevin' conceptualisation as the reference point of future conceptualisations. However, we show 
the existence of at least five conceptualisations of EO, all of which are benchmarked against that of Miller. These conceptualisations display important differences in terms of their dimensions, species, the way in which they are used, the relationship between EO and its dimensions, dimensionality, the possible evolution of the dimensions, and the possible levels of analysis. We summarise the key characteristics of each conceptualisation in Table 1.

Table 1: Comparison of the different conceptualizations of EO

\begin{tabular}{|c|c|c|c|c|c|}
\hline & Original & Unidimensional & Multidimensional & $\begin{array}{l}\text { Three } \\
\text { independently } \\
\text { varying } \\
\text { dimensions }\end{array}$ & $\begin{array}{l}\text { Two lower-order } \\
\text { dimensions }\end{array}$ \\
\hline $\begin{array}{l}\text { Seminal } \\
\text { work }\end{array}$ & Miller 1983 & Covin and Slevin 1991 & $\begin{array}{l}\text { Lumpkin and Dess } \\
1996\end{array}$ & $\begin{array}{l}\text { Kreiser, Marino, } \\
\text { and Weaver, } 2002\end{array}$ & Anderson et al. 2015 \\
\hline Dimensions & $\begin{array}{l}\text { Innovation } \\
\text { Proactiveness } \\
\text { Risk-taking }\end{array}$ & $\begin{array}{l}\text { Innovation } \\
\text { Proactiveness } \\
\text { Risk-taking }\end{array}$ & $\begin{array}{l}\text { Innovation } \\
\text { Proactiveness } \\
\text { Risk-taking } \\
\text { Autonomy } \\
\text { Competitive } \\
\text { aggressiveness }\end{array}$ & $\begin{array}{l}\text { Innovation } \\
\text { Proactiveness } \\
\text { Risk-taking }\end{array}$ & $\begin{array}{l}\text { Two lower-order } \\
\text { dimensions: } \\
\text { entrepreneurial } \\
\text { behaviour } \\
\text { (innovativeness and } \\
\text { proactiveness) and } \\
\text { managerial attitude } \\
\text { towards risk }\end{array}$ \\
\hline Species & $\begin{array}{l}\text { Quantitative } \\
\text { measure of } \\
\text { entrepreneurial } \\
\text { intensity created } \\
\text { as an } \\
\text { independent } \\
\text { variable to } \\
\text { identify what } \\
\text { leads to this } \\
\text { result in } \\
\text { different } \\
\text { organizational } \\
\text { contexts (Miller } \\
\text { 2011) }\end{array}$ & Strategic posture & $\begin{array}{l}\text { Processes, practices, } \\
\text { and decision- } \\
\text { making activities } \\
\text { that lead to new } \\
\text { entry (Lumpkin and } \\
\text { Dess 1996, 137), } \\
\text { and ultimately } \\
\text { performance }\end{array}$ & $\begin{array}{l}\text { Strategic } \\
\text { decision-making } \\
\text { process }(2002,72)\end{array}$ & $\begin{array}{l}\text { Decision-making } \\
\text { practices, } \\
\text { managerial } \\
\text { philosophies, and } \\
\text { strategic behaviours } \\
\text { that are } \\
\text { entrepreneurial in } \\
\text { nature }(2015,1581)\end{array}$ \\
\hline Usage & $\begin{array}{l}\text { Dependent } \\
\text { variable }\end{array}$ & Independent variable & $\begin{array}{l}\text { Independent } \\
\text { variable }\end{array}$ & $\begin{array}{l}\text { Independent } \\
\text { variable }\end{array}$ & Independent variable \\
\hline $\begin{array}{l}\text { Relationshi } \\
\text { p between } \\
\text { EO and its } \\
\text { dimensions }\end{array}$ & Formative & Reflective & Formative & Formative & Formative \\
\hline $\begin{array}{l}\text { Dimensiona } \\
\text { lity }\end{array}$ & $\begin{array}{l}\text { Dimensions } \\
\text { may vary } \\
\text { separately } \\
\text { according to } \\
\text { context (Miller } \\
2011,875 \text { ) }\end{array}$ & $\begin{array}{l}\text { Dimensions co-vary. } \\
\text { EO only exists if the } \\
\text { three dimensions are } \\
\text { present (Covin and } \\
\text { Lumpkin 2011, 862) }\end{array}$ & $\begin{array}{l}\text { Dimensions may } \\
\text { vary independently. } \\
\text { EO is a } \\
\text { superordinate } \\
\text { construct with the } \\
\text { dimensions of risk- } \\
\text { taking, } \\
\text { innovativeness, }\end{array}$ & $\begin{array}{l}\text { Dimensions may } \\
\text { vary } \\
\text { independently } \\
\text { (Kreiser, Marino, } \\
\text { and Weaver 2002, } \\
84 \text { ) according to } \\
\text { the structure }\end{array}$ & $\begin{array}{l}\text { Positive co-variance } \\
\text { between the two } \\
\text { dimensions; both } \\
\text { dimensions are } \\
\text { fundamentally } \\
\text { necessary for EO to } \\
\text { exist }\end{array}$ \\
\hline
\end{tabular}




\begin{tabular}{|c|c|c|c|c|c|}
\hline & & & $\begin{array}{l}\text { proactiveness, } \\
\text { competitive } \\
\text { aggressiveness, and } \\
\text { autonomy being the } \\
\text { constructs that } \\
\text { function as specific } \\
\text { manifestations of } \\
\text { EO (Covin and } \\
\text { Lumpkin 2011, } \\
863) \text {. }\end{array}$ & $\begin{array}{l}\text { (Kreiser and } \\
\text { Davis 2010) }\end{array}$ & \\
\hline $\begin{array}{l}\text { Possible } \\
\text { evolution of } \\
\text { dimensions }\end{array}$ & N/A & $\begin{array}{l}\text { Dimensions may be } \\
\text { added or substituted }\end{array}$ & Dimensions fixed & N/A & $\begin{array}{l}\text { No, dimensions are } \\
\text { not interchangeable }\end{array}$ \\
\hline $\begin{array}{l}\text { Levels of } \\
\text { analysis } \\
\text { possible }\end{array}$ & $\begin{array}{l}\text { Individual, } \\
\text { business } \\
\text { unit/spin-off, } \\
\text { firm, country }\end{array}$ & Business unit & Business unit & N/A & $\begin{array}{l}\text { Firm level (2015, } \\
1593)\end{array}$ \\
\hline
\end{tabular}

Source: the authors. Based upon Anderson et al. (2015); Covin and Slevin (1989, 1991); Covin and Lumpkin (2011); Kreiser and Davis (2010); Kreiser, Marino, and Weaver (2002); Lumpkin and Dess (1996); Miller (1983, 2011).

The original conceptualisation of Miller is widely misunderstood. By identifying Miller's construct as a separate, unique conceptualisation (instead of groundwork leading to alternative conceptualisations) offers interesting research perspectives. For example, it allows us to identify the organisational, contextual, and motivational factors that lead to firm-level entrepreneurial behaviours qualified by the three initial dimensions of EO or establish strategic configurations (Randerson, Bettinelli, and Fayolle 2014). As an outcome, this conceptualisation leaves room for independent study of the antecedents (differing processes, practices, and decision-making activities) but does not replace (is not a proxy for) the study of these organisational factors, as is the case of the four other conceptualisations. It also admits only one possible organisational outcome and thus challenges scholars to identify others.

The works of Kreiser, Marino, and colleagues come closest to continuing this stream in that they develop a three-dimensional, independently varying construct, establishing partial crosscultural validity (Hansen et al. 2011; Kreiser et al. 2010; Kreiser, Marino, and Weaver 2002) as 
well as a theoretical model of the EO-environment-structure-performance relationship (Kreiser and Davis 2010). This work creates a distinct EO construct because although they adopt Miller's dimensions of innovation, proactiveness, and risk-taking, which can vary independently, these dimensions represent the strategic decision-making processes (independent variable) leading to firm performance (dependent variable). In Miller's conceptualisation, these dimensions represent firm-level entrepreneurial behaviour (dependent variable), which can be explained by individual and organisational factors (see Table 1).

The works of Covin and Slevin (1991), which aim to operationalise Miller's conceptualisation, inadvertently create an alternative conceptualisation for two reasons. First, to be qualified as entrepreneurial (having an entrepreneurial strategic posture), the three dimensions co-vary and represent a strategic orientation per se - the 'ultimate dependent variable is firm performance' (Covin and Slevin 1991, 9). As noted previously, this conceptualisation has received the greatest scholarly attention to establish measure validity and as well as a relationship with performance.

The Lumpkin and Dess $(1996,137)$ five-dimensional, independently varying construct represents the 'processes, practices and decision-making activities that lead to new entry' and ultimately performance. This conceptualisation differs from the initial construct in three ways: it is directly a proxy for these organisational activities (instead of trying to identify them), it concerns only the activities leading to new entry, and it admits only these five dimensions.

Finally, the Anderson et al. conceptualisation, grounded in measurement theory, defines two lower-order dimensions: entrepreneurial behaviours (comprising innovativeness and proactiveness) and managerial attitude towards risk. Their conceptualisation represents 'decision- 
making practices, managerial philosophies, and strategic behaviours that are entrepreneurial in nature' $(2015,1581)$, and is designed as an independent variable. For an organisation to be considered entrepreneurial both types of dimensions are necessary and co-variance is required. This conceptualisation does not support any alternative dimensions.

Identifying these different frameworks is important because if our endeavour as scholars is to encourage dialogue and debate (Zahra and Dess 2001), we should also ensure that we are rigorous in our work by identifying the precise conceptual framework for our study, respect its fundamental assumptions (Zahra and Newey 2009), and design our research methods accordingly. We figure in Table 1 the five conceptualisations that we sketch out with the present work and the characteristics of each conceptualisation.

Future research can use our work to identify the conceptualisation within which it is embedded, to respect the framework's basic assumptions about the number and possible evolution of the dimensions, to understand the relationship between the construct and its dimensions, to adopt proper research methods and measurement tools to operationalise the concept, and ultimately to build cumulative bodies of knowledge (Zahra and Newey 2009). As an illustration, research aiming to contribute to EO à la Lumpkin and Dess would mobilise all five dimensions to assume the position of $\mathrm{EO}$ as a proxy for processes and use $\mathrm{EO}$ as an independent variable at the business unit level only. Researchers developing EO à la Lumpkin and Dess would be attentive to draw upon the literature relative to this conceptualisation in order to progressively build a solid body of cumulative knowledge. We delineate the conceptualisations by comparing them with the initial work of Miller; our work can contribute to the identification of other potential conceptualisations. 


\section{Firm-level entrepreneurship behaviour research: Now what?}

The popularity of EO has had positive implications for the construct as well as for the field of entrepreneurship and beyond. In this section, we suggest ways in which to either develop the extant research streams or to boldly open new ways of researching firm-level entrepreneurial behaviour.

\section{Clarifying and developing the extant conceptualisations}

Clarifying the EO construct(s) is necessary to build knowledge of this topic. Indeed, EO research can take several paths. The different conceptualisations may develop separately. Each stream of research could construct its own body of the literature, common assumptions, and distinctive traits (including a name enabling it to be distinguished from the other conceptualisations). Conversely, the research community could agree on what constitutes EO by adopting one conceptualisation. Finally, George and Marino (2011) suggest viewing EO as a family of research, articulated around the three-dimensional, independently varying conceptualisation of firm-level entrepreneurial behaviour. Concurring with Wales (2016), we advocate this last option and hope that the present work will serve as a reference for distinguishing the different conceptualisations and pave the way to building distinct, robust bodies of cumulative knowledge as well as providing a framework for identifying or creating alternative conceptualisations. Keeping these five conceptualisations in mind, we develop below opportunities for challenging the status quo.

First, while considerable effort has been spent on quantifying the construct(s), very little attention has been paid to qualitative methods. Short and colleagues (2010) use computer-aided text analysis techniques in an effort to establish the construct validity of EO based on Lumpkin 
and Dess's conceptualisation. Considering the original design of Miller's conceptualisation, qualitative research designs are desperately needed in order to capture the variety and idiosyncrasies of the processes, uncover and explain the time factor (McMullen and Dimov 2013), and shed light on the interaction of the different levels (e.g. individual, team, organisation). Indeed, for the other four conceptualisations, qualitative-based research designs would capture the detailed and contextualised content of the dimensions (Miller 2011), especially given the discrepancy between the way in which these dimensions are presented in the literature and their actual manifestations. For example, Barbat, Hlady Rispail, and Randerson (2014) show that in the context of exporting established sub-contracting SMEs, risk-taking does not relate to a potentially costly failure but to the psychical distance between the domestic market and the target export market. Here, innovation is not manifested through the creation and improvement of products and/or their adaptation to foreign markets, but rather by focusing on quality to adapt the firm's offer to the needs of its client. Finally, in this context, proactiveness is not reflected in anticipating and acting on future wants and needs in the market but in the search for export information, presence at trade fairs, and networking. Early research in firm level entrepreneurship was qualitative (e.g. Burgleman 1983, 1996; Kanter et al. 1990) and capital to the initial understanding of the phenomenon. More research aiming at a deeper understanding of firm level entrepreneurship and the variety of behaviours which can be qualified as entrepreneurial is greatly needed and qualitative methods are better suited to support this type of research.

Second, for any of the five conceptualisations, the dimensions could be investigated by means other than the scales usually used (Covin and Wales 2012; Lyon, Lumpkin, and Dess 2000; Miller 2011). For example, Miller $(2011,879)$ suggests calling on secondary data such as 
on share price fluctuations (as a proxy of unsystematic risk), $R \& D$ expenditure, patents and patent citations (for innovation), and sales in new markets (new market initiatives). Third, for any of the five conceptualisations, further research could adapt the variables to the specific context or desired outcome to generate cumulative and stable insights (e.g. risk-taking in resource accession or financing, proactiveness in global resource leveraging, and clearly defined types of innovation; Miller 2011, 879).

Fourth, according to the conceptualisation of EO adopted, additional or alternative dimensions could be added. Covin and Lumpkin $(2011,868)$ suggest exploring dimensions related to change or adaptation. Since the behaviours (dimensions) valued as entrepreneurial can differ according to the context, researchers could also draw upon the frameworks suggested in recent research (Welter 2011; Zahra 2007; Zahra and Wright 2011) to structure their investigations in particular geographical contexts (Fayolle, Basso, and Bouchard 2010; Hayton, George, and Zahra 2002; Slevin and Terjesen 2011).

Finally, the study of firm-level entrepreneurial behaviours also carries a specific challenge in terms of the multiple levels to be studied. The firm-level phenomenon is the consequence of the actions of individuals or teams, which differ according to the conceptualisation of EO espoused. We should therefore also focus scholarly attention on the identification of these actors and the dynamics of action (i.e. the interaction with the firm level). The framework offered by Gartner (1985) to describe the phenomenon of new venture creation could support such research. This framework was devised to unveil the idiosyncrasies of organisational emergence for both independent and organisational entrepreneurship (Gartner 1985, 700). It comprises four dimensions: (1) the individual or person(s) involved in creating a new organisation, (2) the organisation or type of venture started, (3) the environment or situation surrounding and 
influencing the new organisation, and (4) the process or actions undertaken by the individual to start the venture. The dimensions together provide a canvas for understanding the phenomena and specificity of each occurrence.

More importantly, opening the scientific study of firm level entrepreneurial behaviours, the original purpose of EO, to other research modes and traditions would allow a more holistic approach.

\section{Opening up the debate to other research modes and traditions}

Entrepreneurship (and thus organisational entrepreneurship) is a multidimensional and multiparadigmatic phenomenon that cannot be fully understood or captured through a single philosophy of science or research tradition (Burg and Romme 2014; Gartner 2013). Extant research studying firm-level entrepreneurial behaviours focuses on EO and EO is embedded in a positivist philosophy of science (Covin and Lumpkin 2011; Covin and Wales 2012). Moreover, as demonstrated in the previous section, EO as it is currently researched precludes unveiling important facets of firm-level entrepreneurial behaviours and unravelling the processes that can lead to them. Other research traditions (e.g. the European tradition) or philosophies of science (e.g. social constructivism and pragmatism) could offer new and fresh perspectives, and more importantly provide the contextualised, multi-level, and longitudinal approaches currently missing. These alternative traditions should not be understood as either/or approaches, but as a means of completing and complementing each other (Gartner 2013).

\section{The European tradition of entrepreneurship research}


The European tradition of entrepreneurship research (Down 2013; Gartner 2013) draws on a broad base of social sciences that includes, but is not restricted to economics. In this research tradition, contextualisation is innate because scientific universalism and positivism are avoided. This opens the door to a wider set of research questions (Hjorth, Jones, and Gartner 2008, 82), and is particularly appropriate for the study of firm-level entrepreneurship because it aims to explicitly link socioeconomic, historical, and cultural contexts to real-life practices (Down 2013). In other words, the European tradition allows us to move from the question of how EO relates to firm performance, where EO is universally recognised as the sole manifestation of firm-level entrepreneurial behaviour, to asking which behaviours can be considered to be entrepreneurial in specific contexts. The answer to this would enable us to understand, for example, how firms that 'reshape global industries' (Boston Consulting Group 2011) actually do so. This is important because EO is a strategic posture (Covin and Slevin 1991) that focuses on competing in a given industry (Lumpkin and Dess 1996) rather than reshaping or creating new ones. Considering that entrepreneurial behaviours are culturally embedded at the national level (Dodd, Jack, and Anderson 2013), as well as at the industry and organisational levels (Fayolle, Basso, and Bouchard 2010), the diversity of the fields of science upon which the European tradition draws would provide a more holistic view than the economic approach currently developed through EO. This would allow us to examine which processes can lead to such behaviours: the idiosyncrasies of entrepreneurial processes and their evolution over time can be understood by observing the process of organisational emergence (Gartner 1985, 1990). The European tradition of entrepreneurship research welcomes research from different philosophies of science. 
Research embedded in a social constructionist perspective allows for multiple 'truths' related to different cultural, historical, and ideological directions and understandings (Ogbor 2000), which affect the construction of entrepreneurial processes. The key question in the social constructionist philosophy of science is 'how entrepreneurial activities are constructed through dialogic, social structural and relational processes' (Fletcher 2007, 165). This is well suited to organisational entrepreneurship research because 'entrepreneurship, like everything else people "know", is a socially constructed reality or concept' (Steyaert and Katz 2004, 186), and is always ongoing, emerging, and becoming (Fletcher 2007). Coviello and Jones (2004), for example, characterise this approach (emic) as culturally specific, whereas an etic approach (positivist) is culturally ubiquitous. It is concerned with linguistic representations, meaning-making, and sense-making processes at the individual and inter-personal level and is inferred from the relationality between individuals, institutions, objects, entities, and language (Fletcher 2006, 422). Social constructionism focuses on the social/relational meanings, interactions, conversations, and discourses at the level of teams, partnerships, and joint acts, admitting the existence of, and allowing us to grasp, multiple perspectives (Fletcher 2007). It is relationally aware when constructing and analysing entrepreneurial accounts, firstly by focusing on the social context of these practices and secondly by showing how, why, and in what ways. Relevant research methods include ethnography, discourse analysis, participant observation, narrative, and biography (Fletcher 2007) and relevant frameworks include 'bricolage' (Baker and Nelson 2005).

A specific illustration would be to extend Spigel's (2013) framework to firm-level entrepreneurship, which is bound by culture on three levels: nation, industry, and organisation (Fayolle, Basso, and Bouchard 2010). Spigel builds on Bourdieu's (1977, 1990) sociology of practice, which views entrepreneurial actions as emerging from actors' comprehension of the 
social rules around them, specifically the 'values' of the forms of capital (economic, cultural, and social) they possess or want to obtain. Bourdieu calls upon three conceptual tools to describe the emergence of practices: field, habitus, and capital. Fields are historically produced social spaces of rules (Bourdieu 1977), the 'rules of the game', in which practices take place, which can help us understand the 'rules' in the three levels of culture. The habitus is how actors develop an understanding of the rules as well as their applicability according to the actor's power or status in the field (Bourdieu 1990), which can help us understand the behaviours of institutions (in the nation), competitors (in the industry), and individuals and teams (in the organisation). The field becomes the context in which practices influenced by the habitus are acted out. This provides an environment in which certain practices make sense. Understanding how these actors identify which practices to enact in relation to multiple fields is crucial to understanding the development of unique entrepreneurial behaviours and their development over time.

More generally, the social constructionist approach allows us to flush out new and interesting research questions to unveil idiosyncratic and holistic portraits of firm-level entrepreneurial behaviours and the mechanisms that induce and hinder them. Considering that this perspective leverages on dialogic, social structural, and relational processes to understand how entrepreneurial activities are constructed (Fletcher 2007), this approach is better apt to capture the interplay and divergence among the actors and levels of analysis proper to the organisational entrepreneurial process, which the normative approach to the phenomenon (EO) does not grasp. For a firm to behave entrepreneurially individuals inside the organisation must take action; however, EO sheds very little light on the individual level of action or the interplay between the individual, team, and organisational levels. For example, in an organisational context, individuals and teams undertake risky projects, many of which fail (Shepherd, Kuratko, 
and Covin 2009). Whereas EO has neglected the "dark side" of entrepreneurship (Birkinshaw 2003), by looking only at how the mechanism of risk and reward mediates an individual's willingness to undertake an entrepreneurial project in an organisation (Monsen, Patzelt, and Saxon 2009) or by identifying that risk leads to unethical behaviours (Karmann et al. 2016), the social constructionist perspective can shed light on how a project fails and grasp the dynamics of failure at different levels as well as the precise levers that lead to unethical behaviours. The model by Ireland, Covin, and Kuratko (2009) analyse the antecedents, elements, and outcomes of a CE strategy, which can be best explored from a social constructionist perspective because it offers the research methods and broader theoretical base needed to understand the actions and interactions among actors and levels.

\section{The pragmatic philosophy of science}

Developing research in a pragmatic perspective, which recognises both the relevance of social construction processes and the presence of a 'real world', can usefully contribute to enriching and expanding the sphere of firm-level entrepreneurship research. The focus is on the entrepreneurial actions and processes in which people engage in particular contexts and times. As Watson (2013) notes, pragmatism is based on the acceptance that there is no proper, fully realised theory of any aspect of life and that scientific knowledge should inform human actions in the world rather than tell us 'what the case is' (positivism). The role of pragmatic research is to facilitate learning, offering different 'how to' practices (in this case, individual and collective actions leading to firm-level entrepreneurship), where the 'how to' constitutes the reality of the situation in a pragmatic worldview. To identify the 'how to' researchers rely on methods such as ethnography, interviews, documentaries, and even surveys as long as they are contextualised to field investigation (Watson 2013). 
Effectuation (Sarasvathy 2001) includes pragmatic elements (Watson 2013) or represents the pragmatic approach in entrepreneurship research (Burg and Romme 2014). Watson (2013) laments the fact that effectuation, as a non-linear process, has been labelled as 'entrepreneurial', whereas a Pragmatist would say 'this is part of the way the social world works' (Watson 2013, 26). In the present work we take effectuation as an application of pragmatism. 'Corporate Effectuation' scales are used to establish a specific outcome (e.g. R\&D performance; Brettel et al. 2012). With this research design, we do not gain insights into the specificities of the effectual entrepreneurial process; they are considered to be fixed (McMullen and Dimov 2013). Effectuation has also been used to understand internal corporate venturing in SMEs (Evald and Senderovitz 2013) as well as opportunity creation and identification (Randerson, Degeorge, and Fayolle 2015). The last two studies although using qualitative methods, also consider effectuation to be fixed (independent variable) and seek to identify a specific outcome (internal corporate venturing or opportunity identification or creation): the idiosyncrasies of the processes are overlooked.

Effectuation can contribute to the EO debate in at least three ways. First, it can be considered to be firm-level entrepreneurial behaviour per se, aiming to reshape environments rather than to act within existing ones (Dew et al. 2008), which could help explain how some firms reshape industries (Boston Consulting Group 2011). Such firm-level behaviours relate to accumulating stakeholder commitments under goal ambiguity, achieving control through nonpredictive strategies, and demonstrating a predominately exaptive orientation (Sarasvathy 2001). Such research would create new and valuable knowledge because EO embraces only a causal approach to entrepreneurship, aiming to 'beat the competitor to the punch' (Miller 1983, 771) rather than creating new industries. 
A second avenue would be to research effectuation (the set of principles) as a method for solving the problems organisations face and the process and levels of problem solving involved (Sarasvathy and Venkataraman 2011). Miller (1983) adopts EO as the dependent variable (firmlevel entrepreneurial behaviours) to unveil the processes and mechanisms that induce or hinder it. Researching firm-level entrepreneurship by using effectuation as the independent variable would thus greatly enrich our knowledge of this entrepreneurial phenomenon and ultimately lead to qualifying behaviours other than innovation, proactiveness, risk-taking autonomy, and competitive aggressiveness.

A third avenue of research concerns organisational design. Effectuation, as a science of the artificial, sees human artefacts as the interface between the inner and outer environments. Organisations are thus human artifacts. Organisational design occurs at both the founder(s)organisational firm interface and the organisation-environment interface. Little is known about how the principles of effectuation affect organisational design and how organisations affect environments (Sarasvathy et al. 2008). Researching this would therefore contribute to the EO debate on the levels to include in the analysis of firm level entrepreneurship. Aligning the philosophy of science, conceptual domain, research methods, and measurement tools is crucial for developing a sound knowledge base. Diversifying the approaches adopted would thus help widen the scope and relevance of the research.

\section{Conclusion}

In the present work, we alert scholars of the shortcomings of extant EO research and profile the five distinct conceptualisations of EO that ground future research around clearly identified constructs as well as their definition, use, and fundamental assumption. This work also facilitates 
the identification of other conceptualisations. We embed EO within the organisational entrepreneurship literature, the first concerning firm-level entrepreneurial behaviours and the second being the entire gamut of activities an organisation undertakes, to demonstrate that the important aspects of firm-level entrepreneurial behaviours remain understudied. Important questions such as what behaviours can be qualified as entrepreneurial, and which processes can lead to such behaviours remain unanswered. Researchers must thus look to traditional EO research as well as other research traditions or philosophies of science to address these outstanding issues.

We show that the European tradition of research can contribute to this debate: the broad array of fields and methods on which this tradition leverages as well as its aim to bridge the gap between real life practices (here, EO) and socioeconomic, historical, and cultural contexts sets the stage for multiple responses to the question of which behaviours can be considered to be entrepreneurial. We show that the processes of organisational emergence shed light on those processes leading to firm-level behaviours.

We also demonstrate how research under alternative philosophies of science can complete the normative/positivist (EO) approach. First, the social constructionist approach is particularly useful for disentangling actions at different levels (individual, team, organisation, and environment) and, in this regard, we offer an extension of Spigel's model (based on Bourdieu's sociology of practice) to firm-level entrepreneurial behaviours. Moreover, we show how this perspective can clarify the interplay and divergence among the actors and levels of action suitable to firm-level entrepreneurship, which the normative approach to EO currently puts in a black box. Second, the pragmatic approach, illustrated by effectuation, can also contribute to building a holistic view of firm-level entrepreneurial behaviours. The principles of effectuation can be 
studied as entrepreneurial behaviours per se (as the dependent variable), as the processes leading to firm-level entrepreneurial behaviours (independent variables), and as organisational design to cast a net on the different levels of actors to analyse.

Our suggestions are made with the aim of enhancing the completeness of research into firm-level entrepreneurial behaviour and of increasing its impact. We hope that our work is useful to structure (normative) EO research around the five conceptualisations described herein, thereby allowing scholars to identify others, and triggering a renewal of this scholarly debate.

Furthermore, we hope that our work creates awareness that very little is known about which firmlevel behaviours can be qualified as 'entrepreneurial' or which processes can lead to such behaviours EO is only one tightly focused approach; hence, to gain a holistic understanding of this phenomenon, contributions from other research traditions and philosophies of science are greatly needed.

\section{References}

Anderson, B. S., P. M. Kreiser, D. F. Kuratko, J. S. Hornsby, and Y. Eshima. 2015. "Reconceptualizing Entrepreneurial Orientation." Strategic Management Journal 36 (10): 15791596.

Avlonitis, G. J., and H.E. Salavou. 2007. "Entrepreneurial Orientation of SMEs, Product Innovativeness, and Performance." Journal of Business Research 60 (5): 566-575.

Baker, T., and R. E. Nelson. 2005. "Creating Something from Nothing: Resource Construction through Entrepreneurial Bricolage.” Administrative Science Quarterly 50 (3): 329-366.

Barbat, V., M. Hlady Rispail, and K. Randerson. 2014. "Disentangling the Roles of International Entrepreneurial Orientation and Networking in the Internationalisation Process of SESBs." International Journal of Entrepreneurship and Small Business 23 (3): 363-384.

Birkinshaw, J. 2003. "The Paradox of Corporate Entrepreneurship." Strategy and Business 30 (Spring): 46-57.

Boston Consulting Group 2011. "Companies on the Move: Rising Stars from Rapidly Developing Economies are Reshaping Global Industries" (White Paper). Boston: BCG.

Bourdieu, P. 1977. Outline of A Theory of Practice. Cambridge: Cambridge University Press.

Bourdieu, P. 1990. The Logic of Practice. Stanford: Stanford University Press. 
Brettel, M., R. Mauer, A. Engelen, and D. Küpper. 2012. “Corporate Effectuation: Entrepreneurial Action and its Impact on R\&D Project Performance." Journal of Business Venturing 27 (2): 167184.

Burgelman, R. A. 1983. "A Process Model of Internal Corporate Venturing in the Diversified Major Firm.” Administrative Science Quarterly 28 (2): 223-244.

Burgelman, R. A. 1996. "A Process Model of Strategic Business Exit: Implications for an Evolutionary Perspective on Strategy.” Strategic Management Journal 17:193-214.

Burg, E., and A. L. Romme. 2014. "Creating the Future Together: Toward a Framework for Research Synthesis in Entrepreneurship.” Entrepreneurship: Theory \& Practice 38 (2): 369-397.

Chimezie, A., and B. Osigweh. 1989. "Concept Fallibility in Organizational Science.” Academy of Management Review 14 (4): 579-594.

Coviello, N. E., and M. V. Jones. 2004. "Methodological Issues in Entrepreneurship Research." Journal of Business Venturing 19 (4): 485-508.

Covin, J. G., and G. T. Lumpkin. 2011. "Entrepreneurial Orientation Theory and Research: Reflections on a Needed Construct." Entrepreneurship: Theory \& Practice 35 (5): 855-872.

Covin, J. G., and D. P. Slevin. 1989. "Strategic Management of Small Firms in Hostile and Benign Environments.” Strategic Management Journal 10 (1): 75-87.

Covin, J. G., and D. P. Slevin. 1991. "A Conceptual Model of Entrepreneurship as Firm Behavior." Entrepreneurship: Theory \& Practice 16 (1): 7-25.

Covin, J. G., and W. J. Wales. 2012. "The Measurement of Entrepreneurial Orientation." Entrepreneurship: Theory \& Practice 36 (4): 677-702.

Covin, J. G., and D. Miller. 2014. "International Entrepreneurial Orientation: Conceptual Considerations, Research Themes, Measurement Issues, and Future Research Directions." Entrepreneurship: Theory \& Practice 38 (1): 11-44.

Dew, N., S. Read, S. D. Sarasvathy, and R. Wiltbank. 2008. "Outlines of a Behavioral Theory of the Entrepreneurial Firm." Journal of Economic Behavior \& Organization 66 (1), 37-59.

Dodd, S. D., S. Jack, and A. R. Anderson. 2013. "From Admiration to Abhorrence: The Contentious Appeal of Entrepreneurship across Europe." Entrepreneurship \& Regional Development 25 (1/2): 69-89.

Down, S. 2013. "The Distinctiveness of the European Tradition in Entrepreneurship Research." Entrepreneurship \& Regional Development 25 (1/2), 1-4.

Evald, M. R., and M. Senderovitz. 2013. "Exploring Internal Corporate Venturing in SMEs: Effectuation at Work in a New Context." Journal of Enterprising Culture 21 (3), 275-299.

Fayolle, A., O. Basso, and V. Bouchard. 2010. "Three Levels of Culture and Firms' Entrepreneurial Orientation: A Research Agenda." Entrepreneurship \& Regional Development 22 (7/8): 707-730.

Fayolle, A. P. Riot, H. Landström, K. Berglund, and W. B. Gartner. 2013. “The Institutionalization of Entrepreneurship: Questioning the Status Quo and Re-gaining Hope for Entrepreneurship Research" Entrepreneurship \& Regional Development 29 (9/10): 889-890. 
Fletcher, D. E. 2006. "Entrepreneurial Processes and the Social Construction of Opportunity." Entrepreneurship \& Regional Development 18 (5), 421-440.

Fletcher, D. E. 2007. "Social Constructionist Thinking: Some Implications for Entrepreneurship Research and Education." In Handbook of Research in Entrepreneurship and Education Volume 1, edited by A. Fayolle, 160-172. Cheltenham (UK): Edward Elgar Publishing.

Gartner, W. B. 1985. "A Conceptual Framework for Describing the Phenomenon of New Venture Creation." Academy of Management Review 10 (4): 696-706.

Gartner, W. B. 1990. "What are we Talking about when we Talk about Entrepreneurship?" Journal of Business Venturing 5: 15-28.

Gartner, W. B. 2007a. "Is there an Elephant in Entrepreneurship? Blind Assumptions in Theory Development." Entrepreneurship Theory and Practice 25 (4): 27-39.

Gartner, W. B. 2007b. "Entrepreneurial Narrative and a Science of the Imagination." Journal of Business Venturing 22 (5): 613-627.

Gartner, W. B. 2013. "Creating a Community of Difference in Entrepreneurship Scholarship." Entrepreneurship \& Regional Development 25 (1/2): 5-15.

Gartner, W. B., B. J. Bird, and J. A. Starr. 1992. “Acting As If: Differentiating Entrepreneurial From Organizational Behavior.” Entrepreneurship: Theory \& Practice 16 (3): 13-31.

George, B. A., and L. Marino. 2011. "The Epistemology of Entrepreneurial Orientation: Conceptual Formation, Modeling, and Operationalization." Entrepreneurship: Theory \& Practice 35 (5): 989-1024.

Hansen, J. D., G. D. Deitz, M. Tokman, L. D. Marino, and K. M. Weaver. 2011. "Cross-national Invariance of the Entrepreneurial Orientation Scale." Journal of Business Venturing 26 (1): 61-78.

Hayton, J. C., G. George, and S. A. Zahra. 2002. "National Culture and Entrepreneurship: A Review of Behavioral Research." Entrepreneurship: Theory \& Practice 26 (4): 33-53.

Hayton, J. C., J. S. Hornsby, and J. Bloodgood. 2013. "Part II: The Contribution of HRM to Corporate Entrepreneurship: A Review and Agenda for Future Research.” M@ N@ Gement 16 (4): 381-409.

Hjorth, D., C. Jones, and W. B. Gartner. 2008. "Introduction for Recreating/Recontextualising Entrepreneurship.” Scandinavian Journal of Management 24 (2): 81-84.

Ireland, R. D., J. G. Covin, and D. F. Kuratko. 2009. "Conceptualizing Corporate Entrepreneurship Strategy.” Entrepreneurship: Theory \& Practice 33 (1): 19-46.

Jennings, D. F., and J. R. Lumpkin. 1989. "Functioning Modeling Corporate Entrepreneurship: An Empirical Integrative Analysis.” Journal of Management 15 (3): 485-503.

Kanter, R. M., J. North, A. P. Bernstein, and A. Williamson. 1990. "Engines of Progress: Designing and Running Entrepreneurial Vehicles in Established Companies." Journal of Business Venturing $5(6), 415$.

Karmann, T., R. Mauer, T. Flatten, and M. Brettel. 2016. "Entrepreneurial Orientation and Corruption." Journal of Business Ethics 133 (2): 223-234. 
Knight, G. A. 1997. "Cross-cultural Reliability and Validity of a Scale to Measure Firm Entrepreneurial Orientation.” Journal of Business Venturing 12 (3): 213-226.

Kreiser, P. M., and J. Davis. 2010. "Entrepreneurial Orientation and Firm Performance: The Unique Impact of Innovativeness, Proactiveness, and Risk-taking." Journal of Small Business \& Entrepreneurship 23 (1): 39-51.

Kreiser, P. M., L. D. Marino, P. Dickson, and M. K. Weaver. 2010. "Cultural Influences on Entrepreneurial Orientation: The Impact of National Culture on Risk Taking and Proactiveness in SMEs.” Entrepreneurship: Theory \& Practice 34 (5): 959-983.

Kreiser, P. M., L. D. Marino, and K. M. Weaver. 2002. "Assessing the Psychometric Properties of the Entrepreneurial Orientation Scale: A Multi-Country Analysis." Entrepreneurship: Theory \& Practice 26 (4): 71-95.

Kuratko, D. F., J. S. Hornsby, D. W. Naffziger, and R. V. Montagno. 1993. "Implement Entrepreneurial Thinking in Established Organizations." SAM Advanced Management Journal (07497075) 58 (1): 28-35.

Li, Y., Y. Liu, and H. Liu. 2011. “Co-opetition, Distributor's Entrepreneurial Orientation and Manufacturer's Knowledge Acquisition: Evidence from China." Journal of Operations Management 29 (1/2): 128-142.

Lumpkin, G. T., C. C. Cogliser, and D. R. Schneider. 2009. "Understanding and Measuring Autonomy: An Entrepreneurial Orientation Perspective." Entrepreneurship: Theory \& Practice 33 (1): 47-69.

Lumpkin, G. T., and G. G. Dess. 1996. "Clarifying the Entrepreneurial Orientation Construct and Linking it to Performance.” Academy of Management Review 21 (1): 135-172.

Lyon, D. W., G. T. Lumpkin, and G. G. Dess. 2000. "Enhancing Entrepreneurial Orientation Research: Operationalizing and Measuring a Key Strategic Decision Making Process." Journal of Management 26 (5): 1055-1085.

McMullen, J. S., and D. Dimov. 2013. "Time and the Entrepreneurial Journey: The Problems and Promise of Studying Entrepreneurship as a Process.” Journal of Management Studies 50 (8): 14811512.

Merz, G. R., and M. H. Sauber. 1995. "Profiles of Managerial Activities in Small Firms." Strategic Management Journal 16 (7): 551-564.

Miller, D. 1983. "The Correlates of Entrepreneurship in Three Types of Firms." Management Science 29 (7): 770-791.

Miller, D. 2011. "Miller (1983) Revisited: A Reflection on EO Research and Some Suggestions for the Future." Entrepreneurship: Theory \& Practice 35 (5): 873-894.

Monsen, E., H. Patzelt, and T. Saxton. (2010). Beyond Simple Utility: Incentive Design and Trade Offs for Corporate Employee-Entrepreneurs. Entrepreneurship: Theory and Practice 34 (1), 105130 .

Ogbor, J. O. 2000. "Mythicizing and Reification in Entrepreneurial Discourse: Ideology-Critique of Entrepreneurial Studies." Journal of Management Studies 37 (5): 605-635. 
Popp, A., and R. Holt. 2013. "Entrepreneurship and Being: The Case of the Shaws." Entrepreneurship \& Regional Development 25 (1/2), 52-68.

Randerson, K., C. Bettinelli, and A. Fayolle. 2014. "A Taxonomic Approach to Entrepreneurial Orientation." In Entrepreneurship, People and Organisations: Frontiers in European Entrepreneurship Research, edited by R. Blackburn, F. Delmar, A. Fayolle, and F. Welter, 51-73. Cheltenham, UK: Edward Elgar.

Randerson, K., J. M. Degeorge, and A. Fayolle. 2016. "Entrepreneurial Opportunities: How do Cognitive Styles and Logics of Action Fit in?" International Journal of Entrepreneurship and Small Business 27 (1): 19-39.

Rauch, A., J. Wiklund, G. T. Lumpkin, and M. Frese. 2009. "Entrepreneurial Orientation and Business Performance: An Assessment of Past Research and Suggestions for the Future." Entrepreneurship: Theory \& Practice 33 (3): 761-787.

Sarasvathy, S. D. 2001. "Causation and Effectuation: Toward a Theoretical Shift from Economic Inevitability to Entrepreneurial Contingency." Academy of Management Review 26 (2): 243-263.

Sarasvathy, S. D., N. Dew, S. Read, S., and R. Wiltbank. 2008. "Designing Organizations that Design Environments: Lessons from Entrepreneurial Expertise." Organization Studies (01708406) 29 (3), 331-350.

Sarasvathy, S. D., and S. Venkataraman. 2011. "Entrepreneurship as Method: Open Questions for an Entrepreneurial Future." Entrepreneurship: Theory \& Practice 35 (1), 113-135.

Satori, G. 1970. "Concept Misformation in Comparative Politics." American Political Science Review 64: 1033-1053.

Sciascia, S., and C. Bettinelli. 2013. "Part III: Corporate Entrepreneurship in Context: 1. Corporate Entrepreneurship in Family Businesses: Past, Present and Future Research.” M@N@Gement 16 (4), 422-432.

Shepherd, D. A., D. F. Kuratko, and J. G. Covin. 2009. "Project Failure from Corporate Entrepreneurship: Managing the Grief Process." Journal of Business Venturing 24: 588-600.

Short, J. C., J. C. Broberg, C. C. Cogliser, and K. H. Brigham. 2010. "Construct Validation Using Computer-Aided Text Analysis (CATA): An Illustration Using Entrepreneurial Orientation." Organizational Research Methods 13 (2): 320-347.

Slevin, D. P., and S. A. Terjesen. 2011. "Entrepreneurial Orientation: Reviewing Three Papers and Implications for Further Theoretical and Methodological Development." Entrepreneurship: Theory \& Practice 35 (5): 973-987.

Spigel, B. 2013. "Bourdieuian Approaches to the Geography of Entrepreneurial Cultures." Entrepreneurship \& Regional Development 25 (9/10): 804-818.

Steyaert, C. and J. Katz. 2004. "Reclaiming the Space of Entrepreneurship in Society: Geographical, Discursive and Social Dimensions." Entrepreneurship \& Regional Development 16: 179-196.

Wales, W. J. 2016. "Entrepreneurial Orientation: A Review and Synthesis of Promising Research Directions." International Small Business Journal 34 (1): 3-15.

Wales, W., E. Monsen, and A. McKelvie. 2011. "The Organizational Pervasiveness of Entrepreneurial Orientation.” Entrepreneurship: Theory \& Practice 35 (5): 895-923. 
Watson, T. J. 2013. "Entrepreneurial Action and the Euro-American Social Science Tradition: Pragmatism, Realism and Looking Beyond 'the Entrepreneur'." Entrepreneurship \& Regional Development 25 (1/2): 16-33.

Welter, F. 2011. "Contextualizing Entrepreneurship-Conceptual Challenges and Ways Forward." Entrepreneurship: Theory \& Practice 35 (1): 165-184.

Williams, C. C., and S. J. Nadin. 2013. "Beyond the Entrepreneur as a Heroic Figurehead of Capitalism: Re-representing the Lived Practices of Entrepreneurs." Entrepreneurship \& Regional Development 25 (7/8), 552-568.

Zahra, S. A., and G. G. Dess. 2001. "Entrepreneurship as a Field of Research: Encouraging Dialogue and Debate." Academy of Management Review 26 (1): 8-10.

Zahra, S. A. 1991. "Predictors and Financial Outcomes of Corporate Entrepreneurship: An Exploratory Study." Journal of Business Venturing 6 (4): 259.

Zahra, S. A. 1993. "A Conceptual Model of Entrepreneurship as Firm Behavior: A Critique and Extension." Entrepreneurship: Theory \& Practice 17 (4): 5-21.

Zahra, S. A. 2007. "Contextualizing Theory Building in Entrepreneurship Research." Journal of Business Venturing 22 (3): 443-452.

Zahra, S. A., and L. R. Newey. 2009. "Maximizing the Impact of Organization Science: TheoryBuilding at the Intersection of Disciplines and/or Fields." Journal of Management Studies 46 (6): 1059-1075.

Zahra, S. A., K. Randerson, and A. Fayolle. 2013. "Part I: The Evolution and Contributions of Corporate Entrepreneurship Research.” M@N@Gement 16 (4): 362-380.

Zahra, S. A., and M. Wright. 2011. "Entrepreneurship's Next Act." Academy of Management Perspectives 25 (4): 67-83.

Zellweger, T., and P. Sieger. 2012. "Entrepreneurial Orientation in Long-Lived Family Firms." Small Business Economics 38 (1): 67-84.

Zellweger, T. M., R. S. Nason, and M. Nordqvist. 2012. "From Longevity of Firms to Transgenerational Entrepreneurship of Families: Introducing Family Entrepreneurial Orientation." Family Business Review 25 (2): 136-155. 